\title{
In-Vitro Screening For the Different Medicinal Plants
}

\author{
Poorna Chandar $\mathrm{G}^{1 *}$, Sree Vennela ${ }^{2}$, V. Rani Samyuktha, Dr.Venkata Ramana \\ Devi .Ch, Srinivas B ${ }^{3}$ \\ Osmania Univrsity Department of Biochemistry Hyderabad
}

\begin{abstract}
Solanum Virginianum L, Azadirachatha Indica, Ocimum Santum, Momoridica Charantia And Aegle Marmelos Herbs Are Extensively Used In Traditional Folk Remedies For A Variety Of Conditions, However, The Plants Possess Anthelmintic And Antimicrobial Activity Potential. The Aim Of The Project Is To Compare All The Herb Extracts For The Above Two Activities Invitro Models. The Phyto Chemical Screening Was Performed For The Above Extracts. The Acute Oral Toxicity Studies Were Performed According To Oecd Guidelines 425.The Aqueous, Petroleum Ether And Methanol Extracts Of S.V.A.I, O.S, M.C And A.M Leaves At The Concentrations Of 12.5 And $25 \mathrm{Mg} / \mathrm{Ml}$ Were Evaluated For Anthelmintic Activity In The Indian Earth Worms Pheritima Posthuma Model By Placing Them In $30 \mathrm{Ml}$ In The Petri Dishes And Observed For The Paralysis And Death. Antimicrobial Activity Was Screened By Cup And Plate Method In The Concentration Of $5 \mathrm{mg}$ Of Leaves Extracts On Gram Positive And Negative Bacteria Zone Of Inhibition Was Measured. From The Results Obtained, We Conclude That The S.V, A.I, O.S,\& A.M, Leaves Extracts At Higher Doses Produces Significant Anthelmintic And Anti-Microbial Activity And Was Comparable To That Produced By Standard Drugs.
\end{abstract}

Keywords: S.V - Solanum Virginium, A.I - Azadirechta Indica, O.S - Ocimum Sanctum, M.C. - Momordica Charantia, A.M. - Aegle Marmelos.

\section{Introduction}

Helminthiasis/,Helmin' Đarəsis/ (Alternatively Spelled Helminthosis; Helminthiases) Is Any Macro Parasitic Disease Of Humans And Animals In Which A Part Of The Body Is Infected With Parasitic Worms, Called Helminthes. These Parasites Are Broadly Classified Into Tapeworms, Flukes, And Roundworms. They Often Live In The Gastrointestinal Tract Of Their Hosts, But May Also Burrow Into Other Organs, Where They Induce Physiological Damages. They Remain The Major Cause Of Wildlife Diseases And Economic Crisis In Livestock Industry, And Human Socio-Economic Problems In Developing Countries. Major Helminthiasis Are Among The Neglected Tropical Diseases Targeted Under The Joint Action Of The World's Leading Pharmaceutical Companies And Non-Government Organizations Through An Ambitious Project Called London Declaration On Neglected Tropical Diseases Which Was Launched On 30 January 2012. It Aims To Control Eradicate The Diseases By 2020, By Ensuring Necessary Supply Of Drugs And Other Intervention, And Promoting Sanitation And Health Education.

Bacteria Are Living Things That Have Only One Cell. Under A Microscope, They Look Like Balls, Rods, Or Spirals. They Are So Small That A Line Of 1,000 Could Fit Across A Pencil Eraser. Most Bacteria Won't Hurt You - Less Than 1 Percent Of The Different Types Make People Sick. Many Are Helpful. Some Bacteria Help To Digest Food, Destroy Disease-Causing Cells, And Give The Body Needed Vitamins. Bacteria Are Also Used In Making Healthy Foods Like Yogurt And Cheese. But Infectious Bacteria Can Make You Ill. They Reproduce Quickly In Your Body. Many Give Off Chemicals Called Toxins, Which Can Damage Tissue And Make You Sick. Examples Of Bacteria That Cause Infections Include Streptococcus, Staphylococcus, And E. Coli. The Human Health Effects Caused By Waterborne, Air Born, Milk Born, And Soil Born Transmission Vary In Severity From Mild Gastroenteritis To Severe And Sometimes Fatal Diarrhoea, Dysentery, Hepatitis And Typhoid Fever. Contaminated Water Can Be The Source Of Large Outbreaks Of Disease, Including Cholera, Dysentery And Cryptosporidiosis; For The Majority Of Waterborne Pathogens, However, There Are Other Important Sources Of Infection, Such As Person To Person Contact And Food. The Air Borne Diseases Are Anthrax, Chicken Pox, Influenza, Measles, Small Pox And Tuberculosis. The Soil Borne Diseases Are Actinomycetoma, Anthrax, Botulism, Campylobacteriosis, Tetanus, Tularaemia, Gangrene, Trichiura, Yersiniosis, Multicularis, Aspergillosis, Blastomycosis, Dermatitis's, Amoebiasis, Is Etc. The Milk Borne Diseases Are Scarlet Fever, Diphtheria, Typhoid Fever, Salmonellosis, Streptococcul Infections Etc. Herb Is A Plant That Is Valued For Flavour, Scent, Medicinal Or Other Qualities. Herbs Are Used In Cooking, As Medicines, And For Spiritual Purposes. Herbs Have A Variety Of Uses Including Culinary, Medicinal, Or In Some Cases Even Spiritual Usage. Herbal Medicines Are Being Used By Nearly About 80\% Of The World Population, Primarily In Developing Countries For Primary Health Care. Assessing The Current Status Of Health Care System In Adequacies Of Synthetic Drugs Is Likely To Be More Glaring In The Coming Years. It 
Has Been Reported That There Has Been An Alarming Increase In Number Of Diseases And Disorders Caused By Synthetic Drugs Prompting A Switch Over To Traditional Herbal Medicine.This Need Has Evoked Extensive Search For New Anti Helmintic And Anti-Microbial Drugs In The Hope Of Being Able To Bridge The Short Comings Of Currently Available Therapies.The Herbs Are Solanum Virginianum L. (S.V), Azadirechta Indica (A.I), Ocimum Sanctum (O.C), Momordica Charantia (M.C) ,And Aegle Marmelos (A.M) Has Been Traditionally Used In India For The Treatment Of Helmenthiasis And Microbial Activity.

Hence, This Study Has Been Taken Up To Evaluate The Antihelmintic Of S.V, A.I, O.S, M.C And A.M In Indian Earthworms And Also Anti-Microbial Activity Has Been Studied With Different Extracts.

\section{Objectives}

Following Are The Objectives Of Present Work

$>$ Collection Of Literature Of Plants Solanum Virginianum L., Azadirechta Indica, Ocimum Sanctum, Momordica Charantia, And Aegle Marmelos.

$>$ Collection Of Plants S.V, A.I, O.S, M.C, And A.M And Authentication.

$>$ Shade Drying And Grinding Of The Plant Leaves.

$>$ Firstly, The Leaves Powder Are Macerated With Water And Dried. And Drugs Extracted Successively With Petroleum Ether, Methanol And Water.

$>$ Soxhlet And Maceration Extracts Percentage Yield Was Calculated.

$>$ Based On Solubility, Complete Extraction Of Phytochemical Constituents Of Leaves Of Solanum Virginianum L., Azadirechta Indica, Ocimum Sanctum Momordica Charantia, And Aegle Marmelos By Using Aqueous, Petroleum Ether And Methanol Solvents.

$>$ Evaluation Of Antihelmintic Activity.

$>$ Evaluation Of Antimicrobial Activity.

$>$ Determination Of $\operatorname{Ld}_{50}$ Value, And Dose Selection For The Study.

\section{Preparation Leaves Extracts Of Plants:}

\section{Methodology}

The Plants Of S.V, A.I, O.S, M.C And Am Was Identified And Authenticated By The Renewed Botanist Professor Baswaraj Lake, Saraswathi Degree College, Vikarabad

After Authentication Of Plants, The Leaves Were Collected In The Month Of January 2013 From The Local Area, And Shade Dried, Until Free From Moisture. Then They Are Subjected To Get A Coarse Powder Of Desired Particle Size.

\section{Preparation Of Leaves Of Extracts: \\ Soxhlet Extraction Method:}

Preparation Of Petroleum Ether Extract:

S.V, A.I, O.S, M.C, And A.M Extractions Were Carried Out By Soxhlet Extraction Method Using Petroleum Ether And Maintained At The Temperature $40^{\circ} \mathrm{c}$. 50gm Of Leaf Powder Were Weighed And Kept In Soxhlet Apparatus, Filled It With $250 \mathrm{Ml}$ Of Petroleum Ether And Extraction Was Carried Out For 12hrs Until No Colour Was Observed In The Siphon. The Solvent Was Separated By Distillation And The Drug Recovered.

\section{Preparation Of Methonalic Extract:}

The Leaf Powders Of S.V, A.I, O.S, M.C, And A.M Extraction Was Carried Out By Soxhlet Extraction Method Using Methanol And Maintained The Temperature Between 40 Load The 50gm Of Leaf Powder And Keep In Soxhlet Apparatus And Fill With 250ml Of Methanol Was Added And Was Carried Out For 14hrs The Solvent Was Separated By Distillation And Drug Is Recovered.

\section{Preparation Of Aqueous Extract:}

The Leaf Powders Of S.V, A.I, O.S, M.C, And A.M Extraction Was Carried Out By Soxhlet Extraction Method Using Water And Maintained The Temperature $80-90^{\circ} \mathrm{c}$ Load The 50gm Of Leaf Powders Were Weight. Keep In Soxhlet Apparatus And Fill With 250ml Of Tap Water Was Added And Was Carried Out For 24hrs The Solvent Separated By Distillation And Drug Is Recovered. 


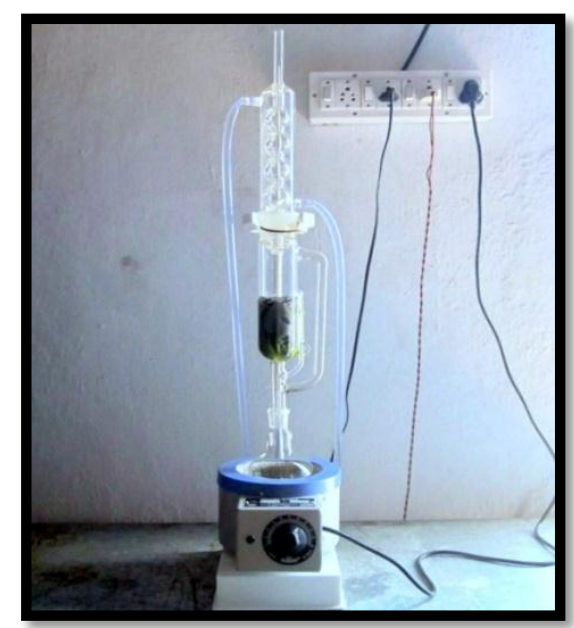

Fig 1: Soxhlet Extractor

\section{Maceration Method:}

The Leaf Powders Of S.V, A.I, O.S, M.C, And A.M Were Soaked In Distilled Water For Cold Maceration At Room Temperature. After One Day The Filtered Was Collected Through A Piece Of Muslin Cloth And Filter Cloth And The Filtrate Was Collect And Dried.
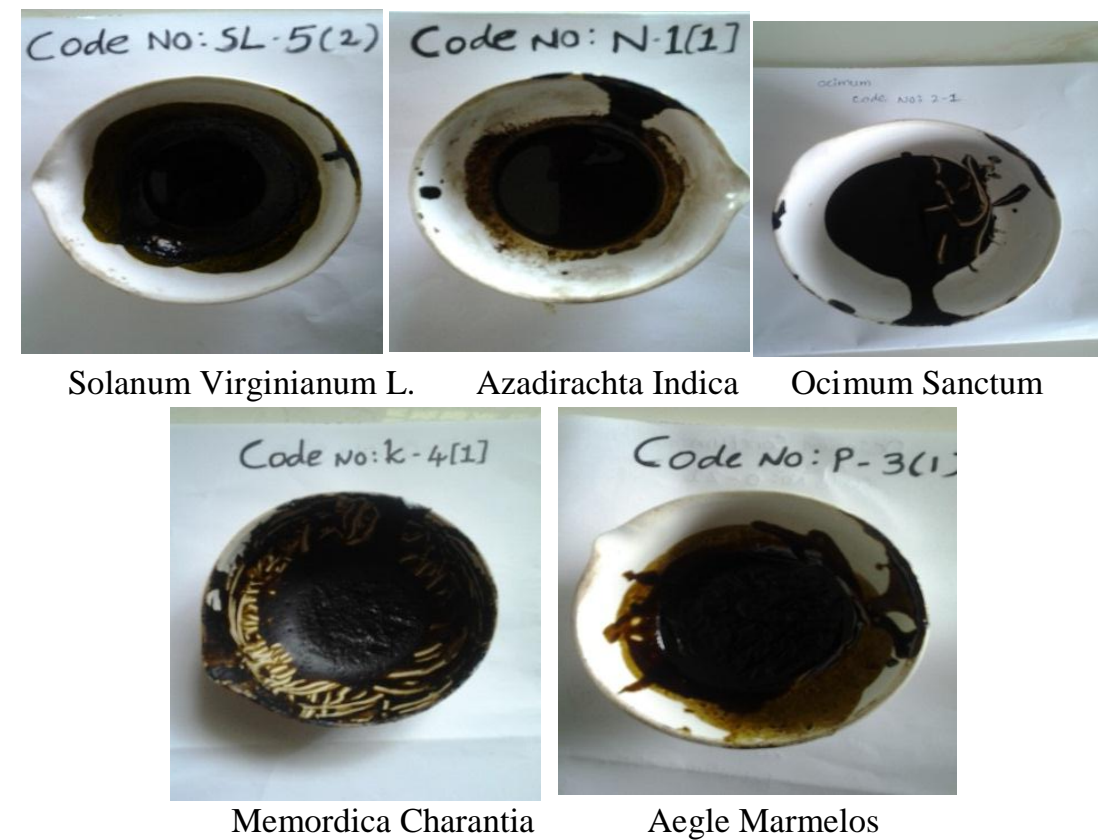

Fig 2: Soxhlet And Macerated Extracts

Phytochemical Analysis:

Preliminary Qualitative Tests

The Extracts Were Subjected To Preliminary Qualitative Phytochemical Investigation. The Various Tests And Reagents Are As Follows:

\section{Alkaloids}

Preparation Of Test Solution: The Test Solution Was Prepared By Dissolving Extracts In The Dilute Hydrochloric Acid Solution.

- Mayer's Test: The Acidic Test Solution With Mayer's Reagent (Pot. Mercuric Iodide) Gave Cream Coloured Precipitate..

- Dragendorff's Test: The Acidic Solution With Dragendorff's Reagent (Potassium Bismuth Iodide) Showed Reddish Brown Precipitate. 
- Wagner's Test: The Acidic Test Solution Treated With Wagner's Reagent (Iodine In Potassium Iodide) Gave Brown Precipitate.

\section{Amino Acids}

Preparation Of Test Solution: Prepared Test Solution By Dissolving The Extract In Water.

- Ninhydrin Test: Test Solution Treated With Ninhydrin Reagent Gave Blue Colour.

3. Carbohydrates:

Preparation Of Test Solution: The Test Solution Was Prepared By Dissolving The Test Extract With Water. Then It Was Hydrolyzed With 1 Volume Of 2n Hcl And Subjected To Following Chemical Tests.

- Molisch's Test: Test Solution With Few Drops Of Molisch's Reagent And 2 Ml Of Conc. $\mathrm{H}_{2} \mathrm{SO}_{4}$ Added Slowly From The Sides Of The Test Tube. It Showed A Purple Ring At The Junction Of Two Liquids.

- Barfoed's Test: Test Solution Treated With Barfoed's Reagent And After Boiling On A Water Bath, It Showed Brick Red Colour Precipitate.

- Benedict's Test: Test Solution Treated With Benedict's Reagent And After Boiling On Water Bath, It Showed Reddish Brown Precipitate.

- Fehling's Test: The Test Solution When Heated With Equal Volume Of Fehling's A And B Solutions, Gave Orange Red Precipitate, Indicating The Presence Of Reducing Sugars.

\section{Flavonoids}

The Flavonoids Are All Structurally Derived From The Parent Substance Called Flavone. The Flavonoids Occur In The Free Form As Well As Bound To Sugars As Glycosides. For This Reason, When Analyzing Flavonoids It Is Usually Better To Examine The Flavonoids In Hydrolyzed Plant Extracts.

\section{Preparation Of Test Solution:}

a) To A Small Amount Of Extract Added Equal Volume Of 2m Hcl And Heated In A Test Tube For 30 To 40 Min. At $100^{\circ} \mathrm{C}$.

b) The Cooled Extract Was Filtered, And Extracted With Ethyl Acetate.

c) The Ethyl Acetate Extract Was Concentrated To Dryness, And Used To Test For Flavonoids.

- Alkaline Reagent Test: Test Solution When Treated With Sodium Hydroxide Solution Showed Increase In The Intensity Of Yellow Colour, Which Becomes Colourless On Addition Of Few Drops Of Dilute Acid.

\section{Glycosides}

Preparation Of Test Solution: The Test Solution Was Prepared By Dissolving Extract In The Alcohol Or Hydro-Alcoholic Solution.

a) Test For Cardiac Glycosides:

- Keller-Killiani Test For Digitoxose: The Test Solution Treated With Few Drops Of $\mathrm{Fecl}_{3}$ Solution And Mixed, Then $\mathrm{H}_{2} \mathrm{SO}_{4}$ Containing $\mathrm{Fecl}_{3}$ Solution Was Added, It Formed Two Layers. Lower Layer Reddish Brown, Upper Layer Turns Bluish Green.

B) Test For Anthraquinone Glycosides:

- Borntrager's Test: Boiled Powdered Drug With 5 Ml Of 10\% Sulphuric Acid For 5 Mins. Filtered While Hot, Cooled The Filtrate Shaken Gently With Equal Volume Of Benzene. Benzene Layer Was Separated And Then Treated With Half Of Its Volume Solution Of Ammonia (10\%). Allowed To Separate It. The Ammonical Layer Acquired Rose Pink Colour Due To The Presence Of Anthraquinones.

\section{Proteins}

Preparation Of Test Solution: The Test Solution Was Prepared By Dissolving The Extract In Water.

- Millon's Test: Test Solution Was Treated With Million's Reagent And Heated On A Water Bath. The Proteins Were Stained Red.

- Biuret Test: Test Solution Was Treated With 40\% Sodium Hydroxide And Dilute Copper Sulphate Solution Gave Blue Colour.

- $\quad$ Test For Proteins Containing Sulphur: Mixed 5 Ml Test Solution With 2 Ml 40\% Naoh And 2 Drops Of 10\% Lead Acetate Solution And Boiled. The Solution Turned Black Or Brownish Due To Lead Sulphate Formation.

\section{Steroids}

Preparation Of Test Extract Solution: The Extracts Were Refluxed Separately With Alcoholic Solution Of Potassium Hydroxide Till Complete Saponification. The Saponified Extract Was Diluted With Water And Unsaponifiable Matter Was Extracted With Diethyl Ether. The Ethereal Extract Was Evaporated And The 
Residue (Unsaponifiable Matter) Was Subjected To The Following Test By Dissolving The Residue In The Chloroform.

- Salkowski Test: To The Test Extract Solution Add Few Drops Of Conc. $\mathrm{H}_{2} \mathrm{SO}_{4}$, Shaken And Allowed To Stand, Lower Layer Turned Red Indicating The Presence Of Sterols.

- Libermann - Burchard Test: The Test Solution Treated With Few Drops Of Acetic Anhydride And Mixed, When Conc. $\mathrm{H}_{2} \mathrm{SO}_{4}$ Was Added From The Sides Of The Test Tube, It Showed A Brown Ring At The Junction Of The Two Layers And The Upper Layer Turned Green.

- Libermann's Reaction: Mixed 3 Ml Extract With 3 Ml Acetic Anhydride, Heated, Cooled. Added Few Drops Of Concentrated $\mathrm{H}_{2} \mathrm{SO}_{4}$. Blue Colour Appeared.

- Sulphur Test: Sulphur When Added In To The Test Solution, It Sank In It.

9. Tannins And Phenol Compounds

To 2-3 Ml Of Alcoholic Or Aqueous Extract, Added Few Drops Of Following Reagents:

- $\quad 5 \%$ Fecl $_{3}$ Solution: Deep Blue-Black Colour.

- Lead Acetate Solution: White Precipitate.

- Dilute Iodine Solution: Transient Red Colour.

10. Triterpenoids

Preparation Of Test Extract Solution: The Test Extract Solution Was Prepared By Dissolving Extract In The Chloroform.

- Salkowski Test: Few Drops Of Concentrated Sulphuric Acid Were Added To The Test Solution, Shaken And On Standing Lower Layer Turned Golden Yellow.

- Libermann - Burchard Test: To The Test Solution Of The Extract, Few Drops Of Acetic Anhydride Were Added And Mixed Well. Then 1 Ml Of Concentrated Sulphuric Acid Added From The Sides Of The Test Tube, A Red Colour Was Produced In The Lower Layer Indicating Presence Of Triterpenes.

\section{Pharmacological Activities}

Determination Of $\operatorname{Ld}_{50}$ Of Leaves Of Extrcts Of Solanum Virginianum L., Azadirechta Indica, Ocimum Sanctum, Momordica Charantia, Aegle Marmelos:

The Acute Toxicity Of Leaves Extracts Of Solanum Virginianum L, Azadirechta Indica, Ocimum Sanctum Momordica Charantia, Aegle Marmelos By Using Female Albino Rats Of Weight Between(150200)G, Maintained Under Standard Condition .The Animals

Were Fasted For 12 Hrs. Prior To The Experiments. Animal Were Administered With Single Dose Of Seeds Extracts Above Plants And Observed For Its Mortality Up To 48 Hrs. Study Period (Short Term Toxicity). Based On The Short- Term Toxicity Profile, The Next Dose Was Decided As Per 0ecd Guidelines No 425.

\section{Antihelmintic Activity:}

The Anthelmintic Activity Was Carried Out As Per The Given By Ajaiyeoba Et Al. The Activity Was Perfomed On Adult Indian Earthworm Pheritima Posthuma Because Of Its Anatomical And Physiological Resemblance With That Of Intestinal Parasites Of Round Worms Of Human Beings. Indian Adult Earth Worms Of Equal Size Were Collected From Vermi Compost At Kothagadi Region, Vikarabad, Rangareddy District, Andhra Pradesh.

Totally Individual 6 Groups Each Containing Crude Extracts Of Sv, Ai, Oc, Mc, Am Standard Drug And Approximately Equal Size Of Earthworms Consisting Six In Each Individual Groups Were Used For The Study. The Samples Of The Extract Were Prepared At The Concentrations Of 12.5mg/Ml, 25mg/Ml In Distilled Water. Each Group Was Placed In Petri Dish Containing 15ml Of The Above Test Solution.

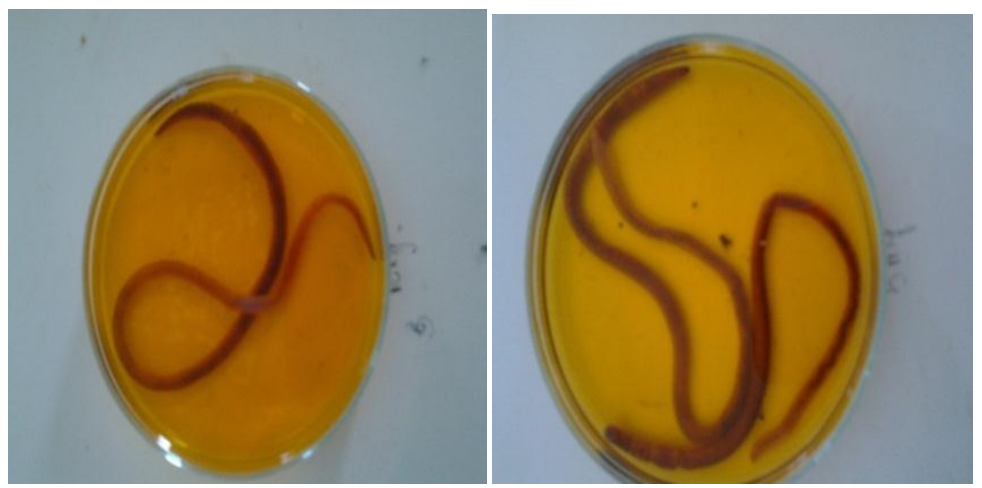




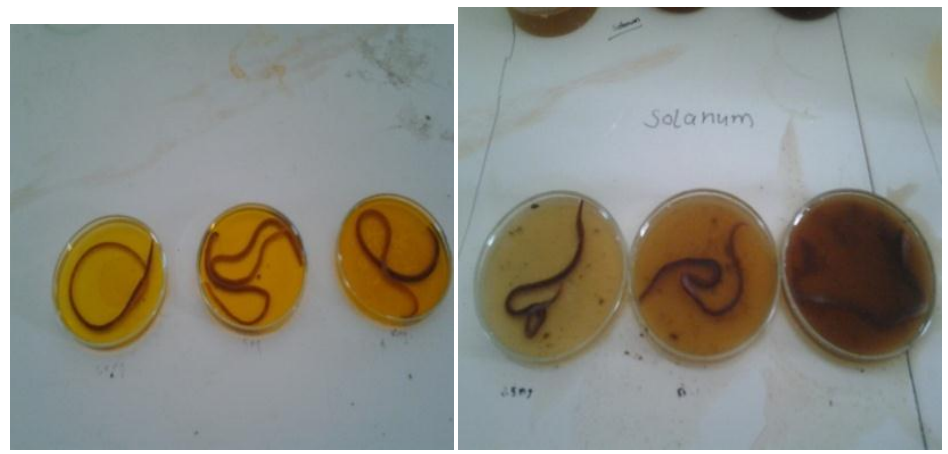

Fig 3: Antihelmentic Activity

Each Group Was Treated As Following:

Group-1: Extracts (Pe, Me And Aq) Of Solanum Virginianum.

Group-2: Extracts (Pe, Me And Aq) Of Azadirechta Indica.

Group-3: Extracts (Pe, Me And Aq) Of Ocimum Sanctum.

Group-4: Extracts (Pe, Me And Aq) Of Memordica Charantia.

Group-5: Extracts (Pe, Me And Aq) Of Aegle Marmelos.

Group-6: Standard Albendazole Drug.

\section{Antimicrobial Activity}

Medicinal Plants Represent A Rich Source Of Antimicrobial Agents. The Development And Spread Of Resistance To The Existing Antibiotics By Microorganisms Are Due To Indiscriminate Use Of Commercial Antimicrobial Drugs Commonly Used In The Treatment Of Various Diseases. Although, A Number Of Plants With Antimicrobial Activities Have Been Identified, Great Number Still Remains Unidentified.

\section{Gram Staining}

Gram Staining Is A Common Technique Used To Differentiate Two Large Groups Of Bacteria Based On Their Different Cell Wall Constituents. The Gram Stain Procedure Distinguishes Between Gram Positive And Gram Negative Groups By Colouring These Cells Red Or Violet. Gram Positive Bacteria Stain Violet Due To The Presence Of A Thick Layer Of Peptidoglycon In Their Cell Walls, Which Retains The Crystal Violet These Cells Are Stained With. Alternatively, Gram Negative Bacteria Stain Red, Which Is Attributed To A Thinner Peptidoglycon Wall, Which Does Not Retain The Crystal Violet During The Decolouring Process.

\section{Procedure:}

Part 1: Preparation Of The Glass Microscopic Slide

Grease Or Oil Free Slides Are Essential For The Preparation Of Microbial Smears. Grease Or Oil From The Fingers On The Slides Is Removed By Washing The Slides With Soap And Water. Wipe The Slides With Spirit Or Alcohol. After Cleaning, Dry The Slides And Place Them On Laboratory Towels Until Ready For Use.

\section{Part 2: Labelling Of The Slides}

Drawing A Circle On The Underside Of The Slide Using A Glassware-Marking Pen May Be Helpful To Clearly Designate The Area In Which You Will Prepare The Smear. You May Also Label The Slide With The Initials Of The Name Of The Organism On The Edge Of The Slide. Care Should Be Taken That The Label Should Not Be In Contact With The Staining Reagents.

\section{Part 3: Preparation Of The Smear}

Bacterial Suspensions In Broth: With A Sterile Cooled Loop, Place A Loopful Of The Broth Culture On The Slide. Spread By Means Of Circular Motion Of The Inoculating Loop To About One Centimetre In Diameter. Excessive Spreading May Result In Disruption Of Cellular Arrangement. A Satisfactory Smear Will Allow Examination Of The Typical Cellular Arrangement And Isolated Cells.

1. Bacterial Plate Cultures: With A Sterile Cooled Loop, Place A Drop Of Sterile Water Or Saline Solution On The Slide. Sterilize And Cool The Loop Again And Pick Up A Very Small Sample Of A Bacterial Colony And Gently Stir Into The Drop Of Water/Saline On The Slide To Create An Emulsion.

2. Swab Samples: Roll The Swab Over The Cleaned Surface Of A Glass Slide. 
Note: It Is Very Important To Prevent Preparing Thick, Dense Smears Which Contain An Excess Of The Bacterial Sample. A Very Thick Smear Diminishes The Amount Of Light That Can Pass Through, Thus Making It Difficult To Visualize The Morphology Of Single Cells. Smears Typically Require Only A Small Amount Of Bacterial Culture. An Effective Smear Appears As A Thin Whitish Layer Or Film After HeatFixing.

\section{Part 4: Heat Fixing}

Heat Fixing Kills The Bacteria In The Smear, Firmly Adheres The Smear To The Slide, And Allows The Sample To More Readily Take Up Stains.

- Allow The Smear To Air Dry.

- After The Smear Has Air-Dried, Hold The Slide At One End And Pass The Entire Slide Through The Flame Of A Bunsen Burner Two To Three Times With The Smear-Side Up.

Now The Smear Is Ready To Be Stained.

Note: Take Care To Prevent Overheating The Slide Because Proteins In The Specimen Can Coagulate Causing Cellular Morphology To Appear Distorted.

\section{Part 5: Gram Stain Procedure}

1. Place Slide With Heat Fixed Smear On Staining Tray.

2. Gently Flood Smear With Crystal Violet And Let Stand For 1 Minute.

3. Tilt The Slide Slightly And Gently Rinse With Tap Water Or Distilled Water Using A Wash Bottle.

4. Gently Flood The Smear With Gram's Iodine And Let Stand For 1 Minute.

5. Tilt The Slide Slightly And Gently Rinse With Tap Water Or Distilled Water Using A Wash Bottle. The Smear Will Appear As A Purple Circle On The Slide.

6. Decolorize Using 95\% Ethyl Alcohol Or Acetone. Tilt The Slide Slightly And Apply The Alcohol Drop By Drop For 5 To 10 Seconds Until The Alcohol Runs Almost Clear. Be Careful Not To OverDecolorize.

7. Immediately Rinse With Water.

8. Gently Flood With Safranin To Counter-Stain And Let Stand For 45 Seconds.

9. Tilt The Slide Slightly And Gently Rinse With Tap Water Or Distilled Water Using A Wash Bottle.

10. Blot Dries The Slide With Bibulous Paper. View The Smear Using A Light-Microscope Under OilImmersion.

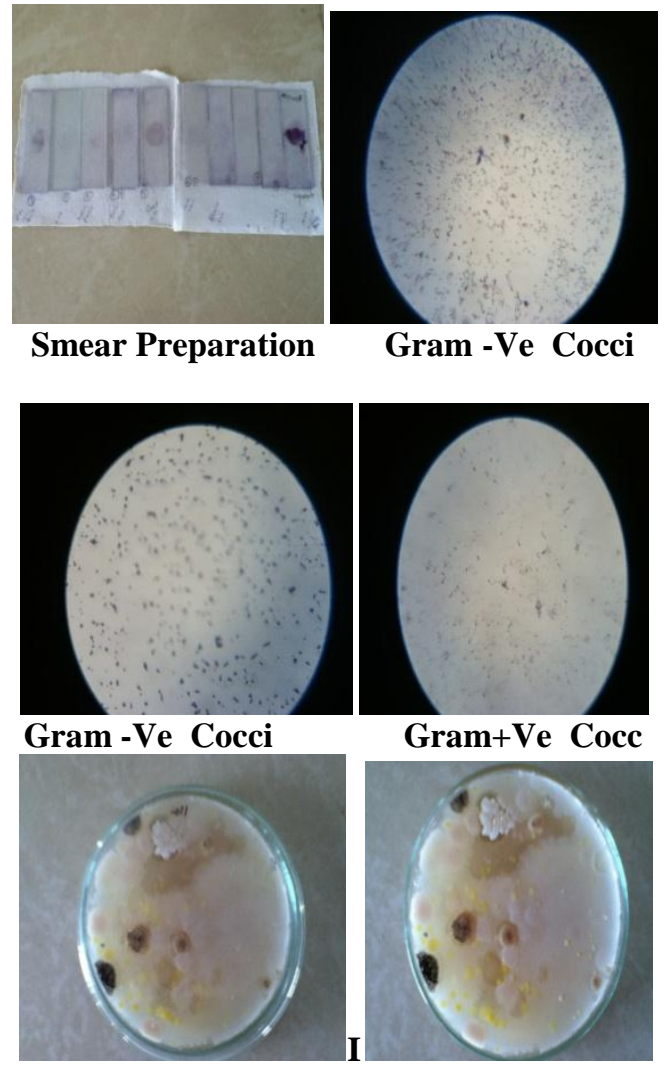

Fig 4: Bacterial Growth 


\section{Results}

Qualitative Chemical Examination Of Extracts Of M.C, A,M

\begin{tabular}{|l|l|l|}
\hline \multirow{4}{*}{ Solanum Virginium } & Aqueous Extract & $1 \mathrm{~cm}-1.2 \mathrm{~cm}$ \\
\cline { 2 - 3 } & Petroleum Ether Extract & $0.9 \mathrm{~cm}-1.3 \mathrm{~cm}$ \\
\cline { 2 - 3 } & Methanolic Extract & $1.0 \mathrm{~cm}-1.4 \mathrm{~cm}$ \\
\hline \multirow{4}{*}{ Ocimum Sanctum } & Macerated Extract & $1.0 \mathrm{~cm}-1.3 \mathrm{~cm}$ \\
\cline { 2 - 3 } & Aqueous Extract & $0.9 \mathrm{~cm}-1.3 \mathrm{~cm}$ \\
\cline { 2 - 3 } & Petroleum Ether Extract & $0.8 \mathrm{~cm}-1.2 \mathrm{~cm}$ \\
\cline { 2 - 3 } & Methanolic Extract & $0.8 \mathrm{~cm}-1.3 \mathrm{~cm}$ \\
\hline \multirow{5}{*}{ Momordica Charantia } & Macerated Extract & $0.7 \mathrm{~cm}-0.9 \mathrm{~cm}$ \\
\cline { 2 - 3 } & Aqueous Extract & $0.6 \mathrm{~cm}-0.9 \mathrm{~cm}$ \\
\cline { 2 - 3 } & Petroleum Ether Extract & $0.7 \mathrm{~cm}-1.0 \mathrm{~cm}$ \\
\cline { 2 - 3 } & Methonolic Extract & $0.6 \mathrm{~cm}-1.0 \mathrm{~cm}$ \\
\hline & Macerated Extract & $0.9 \mathrm{~cm}-1.4 \mathrm{~cm}$ \\
\cline { 2 - 3 } & Aqueous Extract & $0.9 \mathrm{~cm}-1.3 \mathrm{~cm}$ \\
\cline { 2 - 3 } & Petroleum Ether Extract & $0.8 \mathrm{~cm}-1.3 \mathrm{~cm}$ \\
\cline { 2 - 3 } & Methanolic Extract & $0.9 \mathrm{~cm}-1.4 \mathrm{~cm}$ \\
\hline \multirow{5}{*}{ Aegle Marmelos } & Macerated Extract & $0.9 \mathrm{~cm}-1.2 \mathrm{~cm}$ \\
\cline { 2 - 3 } & Aqueous Extract & $0.8 \mathrm{~cm}-1.3 \mathrm{~cm}$ \\
\cline { 2 - 3 } & Petroleum Ether Extract & $0.9 \mathrm{~cm}-1.4 \mathrm{~cm}$ \\
\cline { 2 - 3 } & Methanolic Extact & $0.7 \mathrm{~cm}-1.4 \mathrm{~cm}$ \\
\hline Standard Drug (Tetracycline) & & $0.9 \mathrm{~cm}-1.5 \mathrm{~cm}$ \\
\hline
\end{tabular}

\section{Antihelmintic Activity}

Table No: 5

\begin{tabular}{|c|c|c|c|c|}
\hline \multirow[b]{2}{*}{ Drug } & \multirow{2}{*}{ Type Of Extracts } & \multirow{2}{*}{ Concentration(Mg/Ml) } & \multicolumn{2}{|c|}{ Time In Minutes } \\
\hline & & & $\begin{array}{l}\text { Paralysis } \\
\text { Time }\end{array}$ & Death Time \\
\hline \multirow{6}{*}{ S.Virginianum L. } & \multirow[t]{2}{*}{ Aqueous } & 12.5 & $80 \mathrm{~min}$ & $105 \mathrm{~min}$ \\
\hline & & 25 & $75 \mathrm{~min}$ & $98 \mathrm{~min}$ \\
\hline & \multirow{2}{*}{ Petroleum Ether } & 12.5 & $78 \mathrm{~min}$ & $95 \mathrm{~min}$ \\
\hline & & 25 & 70min & $87 \mathrm{~min}$ \\
\hline & \multirow[t]{2}{*}{ Methanolic } & 12.5 & $71 \mathrm{~min}$ & $83 \mathrm{~min}$ \\
\hline & & 25 & $66 \mathrm{~min}$ & $79 \mathrm{~min}$ \\
\hline \multirow{6}{*}{ A.Indica } & \multirow[t]{2}{*}{ Aqueous } & 12.5 & $200 \mathrm{~min}$ & $275 \mathrm{~min}$ \\
\hline & & 25 & $175 \mathrm{~min}$ & $200 \mathrm{~min}$ \\
\hline & \multirow{2}{*}{ Petroleum Ether } & 12.5 & $179 \min$ & 199min \\
\hline & & 25 & $170 \mathrm{~min}$ & $196 \mathrm{~min}$ \\
\hline & \multirow[t]{2}{*}{ Methanolic } & 12.5 & $168 \mathrm{~min}$ & $187 \mathrm{~min}$ \\
\hline & & 25 & $128 \mathrm{~min}$ & $169 \mathrm{~min}$ \\
\hline \multirow{6}{*}{ O.Sanctum } & \multirow[t]{2}{*}{ Aqueous } & 12.5 & $85 \mathrm{~min}$ & $140 \mathrm{~min}$ \\
\hline & & 25 & $60 \mathrm{~min}$ & $90 \mathrm{~min}$ \\
\hline & \multirow{2}{*}{ Petroleum Ether } & 12.5 & $65 \mathrm{~min}$ & $100 \mathrm{~min}$ \\
\hline & & 25 & $70 \mathrm{~min}$ & $85 \mathrm{~min}$ \\
\hline & \multirow[t]{2}{*}{ Methanolic } & 12.5 & $80 \mathrm{~min}$ & $95 \mathrm{~min}$ \\
\hline & & 25 & $73 \mathrm{~min}$ & $90 \mathrm{~min}$ \\
\hline \multirow{6}{*}{ M.Charantia } & \multirow[t]{2}{*}{ Aqueous } & 12.5 & $90 \mathrm{~min}$ & $105 \mathrm{~min}$ \\
\hline & & 25 & $80 \mathrm{~min}$ & $95 \mathrm{~min}$ \\
\hline & \multirow{2}{*}{ Petroleum Ether } & 12.5 & $85 \mathrm{~min}$ & $96 \mathrm{~min}$ \\
\hline & & 25 & $78 \mathrm{~min}$ & $87 \mathrm{~min}$ \\
\hline & \multirow{2}{*}{ Methanolic } & 12.5 & $75 \mathrm{~min}$ & $89 \mathrm{~min}$ \\
\hline & & 25 & $70 \mathrm{~min}$ & $83 \mathrm{~min}$ \\
\hline \multirow{6}{*}{ A. Marmelos } & \multirow[t]{2}{*}{ Aqueous } & 12.5 & $190 \mathrm{~min}$ & $275 \mathrm{~min}$ \\
\hline & & 25 & $170 \mathrm{~min}$ & $250 \mathrm{~min}$ \\
\hline & \multirow{2}{*}{ Petroleum Ether } & 12.5 & 169 min & $201 \mathrm{~min}$ \\
\hline & & 25 & $160 \mathrm{~min}$ & $189 \min$ \\
\hline & \multirow[t]{2}{*}{ Methanolic } & 12.5 & $157 \mathrm{~min}$ & $187 \mathrm{~min}$ \\
\hline & & 25 & $140 \mathrm{~min}$ & $170 \mathrm{~min}$ \\
\hline \multirow[b]{2}{*}{ Albendazole } & & 12.5 & $38 \mathrm{~min}$ & 70min \\
\hline & & 25 & $30 \mathrm{~min}$ & $60 \mathrm{~min}$ \\
\hline
\end{tabular}


Although A Panel Of Drugs Has Been Developed For The Treatment Of Antihelmintic And Antibacterial, Therapies Are Not Satisfied With These Marketed Drugs. In This Present Context, An Attempt To Study Was Proposed To Evaluate The Effects Of Solanum Virginianum L, Azadirechta Indica, Ocimum Sanctum Momordica Charantia, Aegle Marmelos Leaves Extracts On Antihelmintic And Anti-Bacterial. In The Present Study, The Antihelmintic And Antibacterial Activity Of Petroleum Ether, Methanolic And Aqueous Extract Of Solanum Virginianum L, Azadirechta Indica, Ocimum Sanctum, Momordica Charantia , Aegle Marmelos Leaves Was Carried Out.

Solanum Virginium :

The Solanum Virginium Methanolic Extracts Of Low Dose (12.5mg/Ml) Shows Less Activity Than High Dose (25mg/Ml) The Solanum Virginium Aqueous Extracts Of Low Dose(12.5mg/Ml) Shows Poor Anthelmintic Activity.

Azadirachta Indica:

From The Above Results The Azadirachta Indica Methonolic Extract Higher Dose (25mg/Ml) Shown Dose Dependent Activity Comparable To The Standard Followed By Low Dose Of The Methanolic Extract. From All These The Poor Activity Was Shown By Aqueous Low Dose (12.5mg/Ml).

Ocimum Sanctum:

From Above Results The Ocimum Sanctum Aqueous Extract Higher Dose(25mg/Ml) Shown Dose Dependent Activity Comparable To The Standard Followed By Low Dose Of The Petroleum Ether Extract From All These The Poor Activity Was Shown By Aqueous Low Dose (12.5mg/Ml).

Memordica Charantia:

From Above Results The M.Charantia Methanolic Extracts Higher Dose (25mg/Ml) Shown Dependent Activity Comparable To The Standard Followed By Low Of The Methanolic Extracts From All These. The Poor Activity Was Shown By Aqueous Low Dose (12.5mg/Ml)

Aegle Marmelos:

From Above Results The A.Marmelos Methanolic Extract Higher Dose (25mg/Ml) Shown Dependent Activity Comparable To The Standard Followed By Low Dose Of The Methanolic Extract From All These. The Poor Activity Was Shown By Aqueous Low Dose (12.5mg/Ml).

\section{Anti Microbial Activity:}

The Petroleum Ether, Methanol, Aqueous And Macerated Extracts Were Examined For Their Antibacterial Potency By Cup Plate Method Against Gram Positive Bacterial Species (Cocci And Bacilli). Petri Plates Were Prepared With Nutrient Agar Media.1ml Inoculums Suspension Was Swabbed Uniformly Over The Agar Medium To Get Uniform Distribution Of Bacteria. These Plates Were Labelled And 50mg Of Each Plant Extracts Was Added Aseptically Into The Agar Plate. Tetracycline Was Used As Positive Control. The Petri Plates Were Then Incubated At $37^{\circ} \mathrm{C}$ For 24 Hrs During Which The Activity Was Evidenced By The Presence Of Zone Of Inhibition Surrounding The Plant Extract. The Negative Control Was Prepared Using Respective Solvent. The Zone Of Inhibition Was Measured And Expressed In Millimetres.
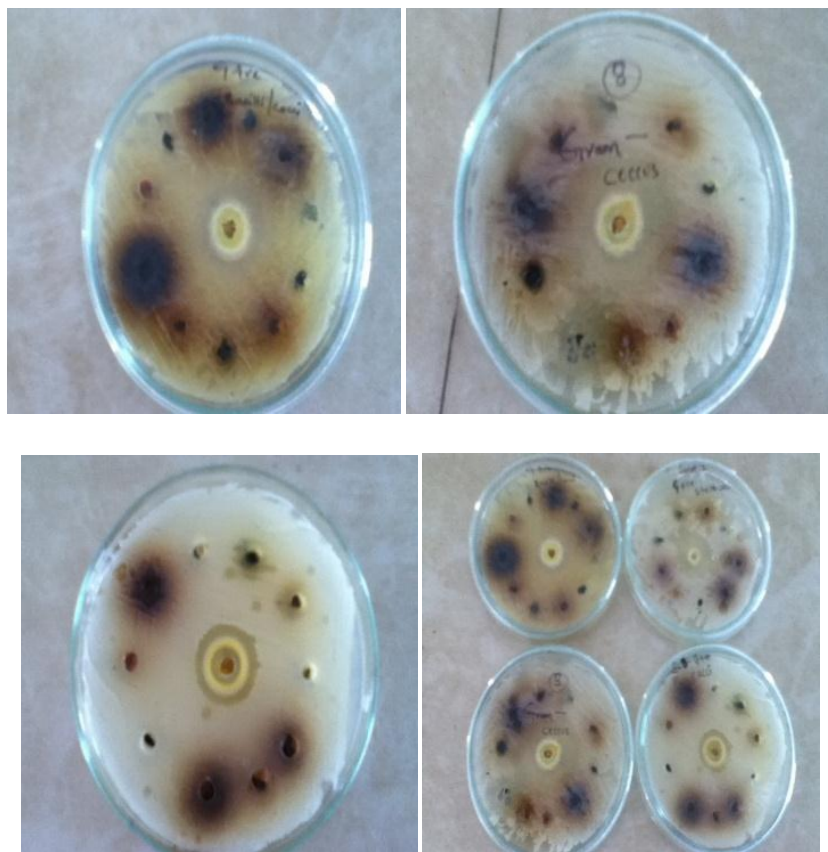

Fig.5: Zone Of Inhibition 
The Results Of Diameters Of The Zones Of Inhibition Of Extracts And Antibiotic Are Presented In Table.

Table No: 5 Zone Of Inhibition

\begin{tabular}{|l|l|l|}
\hline Plant Name & Types Of Extracts & Inhibition Area (In Cm) \\
\hline \multirow{4}{*}{ Solanum Virginium } & Aqueous Extract & $1 \mathrm{~cm}-1.2 \mathrm{~cm}$ \\
\cline { 2 - 3 } & Petroleum Ether Extract & $0.9 \mathrm{~cm}-1.3 \mathrm{~cm}$ \\
\cline { 2 - 3 } Azadirechta Indica & Methanolic Extract & $1.0 \mathrm{~cm}-1.4 \mathrm{~cm}$ \\
\hline \multirow{5}{*}{ Ocimum Sanctum } & Macerated Extract & $1.0 \mathrm{~cm}-1.3 \mathrm{~cm}$ \\
\cline { 2 - 3 } & Aqueous Extract & $0.9 \mathrm{~cm}-1.3 \mathrm{~cm}$ \\
\cline { 2 - 3 } & Petroleum Ether Extract & $0.8 \mathrm{~cm}-1.2 \mathrm{~cm}$ \\
\cline { 2 - 3 } & Methanolic Extract & $0.8 \mathrm{~cm}-1.3 \mathrm{~cm}$ \\
\hline \multirow{5}{*}{ Momordica Charantia } & Macerated Extract & $0.7 \mathrm{~cm}-0.9 \mathrm{~cm}$ \\
\cline { 2 - 3 } & Aqueous Extract & $0.6 \mathrm{~cm}-0.9 \mathrm{~cm}$ \\
\cline { 2 - 3 } & Petroleum Ether Extract & $0.7 \mathrm{~cm}-1.0 \mathrm{~cm}$ \\
\cline { 2 - 3 } & Methonolic Extract & $0.6 \mathrm{~cm}-1.0 \mathrm{~cm}$ \\
\hline \multirow{5}{*}{ Aegle Marmelos } & Macerated Extract & $0.9 \mathrm{~cm}-1.4 \mathrm{~cm}$ \\
\cline { 2 - 3 } & Aqueous Extract & $0.9 \mathrm{~cm}-1.3 \mathrm{~cm}$ \\
\cline { 2 - 3 } & Petroleum Ether Extract & $0.8 \mathrm{~cm}-1.3 \mathrm{~cm}$ \\
\cline { 2 - 3 } & Methanolic Extract & $0.9 \mathrm{~cm}-1.4 \mathrm{~cm}$ \\
\hline Standard Drug (Tetracycline) & Macerated Extract & $0.9 \mathrm{~cm}-1.2 \mathrm{~cm}$ \\
\cline { 2 - 3 } & Aqueous Extract & $0.8 \mathrm{~cm}-1.3 \mathrm{~cm}$ \\
\cline { 2 - 3 } & Petroleum Ether Extract & $0.9 \mathrm{~cm}-1.4 \mathrm{~cm}$ \\
\cline { 2 - 3 } & Methanolic Extact & $0.7 \mathrm{~cm}-1.4 \mathrm{~cm}$ \\
\hline
\end{tabular}

The Antimicrobial Activity Was Screened Extracts Against Gram Positive And Gram Negative Coccus, The Results Were Compared With Standard Drug (Tetracycline). The Extracts Exhibited Significant Antimicrobial Activity.

Solanum Virginium L: From All The Above The Three Extacts, Methanolic Extracts Shows Higher

Zone Of Inhibition Followed By Petroleum Either And Least Was Aqueous.

Ocimum Sanctum:

From All The Three Extracts Shows Higher Zone Of Inhibition Followed By Petroleum Ether And Least Was Methonolic

Azadirachta Indica:

From All The Three Extracts Shows Higher Zone Of Inhibition Followed By The Macerated And Least Was Methonolic Extracts.

Aegle Marmelos:

From All The Three Extracts Shows Higher Zone Of Inhibition Followed By The Petroleum Ether And Least Was Aqueous.

Momordica Charantia:

From All The Three Extracts Shows Higher Zone Of Inhibition Followed By The Methanol And Least Was Petroleum Ether. The Antimicrobial Activity Was Screened Extracts Against Gram Positive And Gram Negative Coccus, The Results Were Compared With Standard Drug (Tetracycline). The Extracts Exhibited Significant Antimicrobial Activity.

Solanum Virginium L:

From All The Above The Three Extacts, Methanolic Extracts Shows Higher Zone Of Inhibition Followed By Petroleum Either And Least Was Aqueous.

\section{Conclusion}

Although A Panel Of Drugs Has Been Developed For The Treatment Of Antihelmintic And Antibacterial, Therapies Are Not Satisfied With These Marketed Drugs. In This Present Context, An Attempt To Study Was Proposed To Evaluate The Effects Of Solanum Virginianum L, Azadirechta Indica, Ocimum Sanctum, Momordica Charantia And Aegle Marmelos Leaves Extracts On Antihelmintic And Anti-Bacterial. In The Present Study, The Antihelmintic And Antimicrobial Activity Of Petroleum Ether, Methanolic And Aqueous Extract Of S.V, A.I, O.C, M.C, And A.M Leaves Was Carried Out.The Antihelmintic And AntiBacterial Activity Of Petroleum Ether And Methanolic And Aqueous Extracts Of S.V, A.I, O.C, M.C And A.M Leaves Observed In The Present Study Might Be Due To Presence Chemical Constituentes Like Saponins, Terpenoids, Alkaloids, Flavonoids. Presence Of These Phytoconstituents Is Reported To Be Responsible For Antihelmintic And Antimicrobial Activity. Antihelmintic Activity. Due To The Presence Of Secondary Metabolite I.E. Tannins, Alkaloids, Flavonoids In The Leaves Extracts Of S.V,O.S, M.C And A.M. The Compounds Shown Anthelminticactivity, Chemically Tannins Are Polyphenolic Compounds. Some 
Synthetic Phenolic Antihelmintics E.G., Niclosamide, Oxyclozanide And Bithionol Are Shown To Interfere With Energy Generation In Helminth Parasites By Uncoupling Oxidative Phosphorylation .It Is Possible That Tannins Contained In The Above Extracts Produced Similar Effects. Another Possible Anthelmintic Effect Of Tannins, F Is That They Can Bind To Free Protein In The Gastrointestinal Tract Of Host Animal Or Glycoprotein On Cuticle Of The Parasite And Cause Death. The A.I Contains The Nimbicin And Azarichin These Are Causes The Inhibit The Cell Wall Synthesis Its Leads The Paralysis And Death Of The Helminths. From All The Above Extracts Solanum Virginianum L. Extract Shows Higher Antihelmintic And Antimicrobial Activity And Azadirechta Indica Aqueous Extract Shows Poor Antihelmintic Activity And All The Extracts Solanum Virginianum L. Methanolic Extracts Shows Higher Zone Of Inhibition And Memordica Charantia Shows Lesser Zone Of Inhibition. Further Studies Had To Be Carried Out For The Isolation Of Active Constituents Responsible For The Above Activities. Now A Days Most Of The Synthetic Drugs Are Not Only Inaccessible And Unaffordable, But Also Possess Many Toxic Adverse Effects. Therefore, There Is Great Need For The Development Of Effective, Safe And Cheap Antihelmintic And Anti-Microbial Agents From Plants And Other Alternative Sources. In Folklore Medicines Solanum Virginianum L., Azadirachta Indica, Ocimum Sanctum Momordica Charantia And Aegle Marmelos Are Used In The Treatment Of Helmintic And Microbial Activity. However, There Are Not Adequate Experimental Evidences About The Effectiveness Of S.V, A.I, O.S, M.C And A.M Leaves As Antihelmintic And Anti-Microbial Activity. In This Present Context, An Attempt Of Study Is Proposed To Evaluate The Effect Of Above All Herbs Leaves Extracts On Helmentic In Indian Earth Worms And Microbial Activity On Several Micro-Organisms. Dried Leaves Of S.V, A.I, O.C, M.C And A.M Were Powedered And Subjected To Successive Extraction In Soxhlet Apparatus Using Petroleum Ether, Methanol And Water. All The Extracts Were Administered To The Animals Using For Experimental Purpose. Preliminary Phytochemical Examination Of S.V, A.I, O.C, M.C And A.M Leaves Extracts Were Done For The Determining Various Phytoconstituents. Flavanoids, Proteins, Sterols And Tannins, Carbohydrates, Alkaloids And Glycoside Were Found To Be Present. Acute Oral Toxicity $\left(\operatorname{Ld}_{50}\right)$ Of Petroleum Ether, Methanolic And Water Extracts Of Solanum Virginianum L., Azadirachta Indica, Ocimum Sanctum Momordica Charantia And Aegle Marmelos Leaves Extracts Were Determined In Albino Rats As Per Oecd Guidelines No.425 Up To Dose Levels Of $2000 \mathrm{Mg} / \mathrm{Kg}$ And It Was Found That These Extracts Were Non-Toxic Even At $2000 \mathrm{Mg} / \mathrm{Kg}$ Dose And No Mortality Was Recorded. The Antihelmintic Activity Was Determined By Using Indian Earth Worm Pheritima Postuma. The Leaves Of Crude Extracts Petroleum Ether, Methanol And Water Extracts Of S.V, A.I, O.S, M.C And A.M Indifferent Concentrations Shows The Significant Activity Compared That Of The Standard Drug. In The S.V, A.I, O.S, M.C And A.M Of Methanolic Extracts, And Ocimum Sanctum Petroleum Ether Extract Are Showed More Significant Result And Was Compared That Of The Standard. The Anti-Microbial Activity Was Done Crude Extracts Leaves Petroleum Ether, Methanol And Water Extracts Of S.V, A.I, O.S, M.C And A.M Are Showed More Significant Activity Compare That Of The Standard Drug Against Gram Positive And Gram Negative Bacteria.Retrospective Reports Reveal That, The Phytoconstituents Such As Flavonoids And Alkaloids Etc. Are Responsible Moieties In Most Of The Plants For Their Antihelmintic And Antimicrobial Activities. Indeed, Petroleum Ether, Methanol And Water Extracts Of S.V, A.I, O.S, M.C And A.M Have Shown Positive Test. However, There Is Need To Isolate And Characterize The Phytoconstituents Responsible For Antihelmintic And Anti-Microbial Activity. There Is Also A Need To Focus On Its Exact Mechanism Of Action.

\section{References}

[1] London Declaration (30 January 2012). "London Declaration On Neglected Tropical Diseases". Retrieved 2013-03-26.

[2] Http://Www.Surgistrategies.Com/Articles/2005/12/Gram-Positive-And-Gram Negative-Bacteria.Aspx

[3] K R, Kirtikar, B D Basu, "Ocimum Sanctum In Indian Medicinal Plants" (Published By Lb Basu, Allahabad), 1965.

[4] [1] B. Goldberg. Alternative Medicine: The Definitive Guide. Future Medicine Publishers,Puyallup, Washington, $1994,257$.

[5] S.T. Ghule, D.K. Patil. Kisan World, 2001,28 (10), 33-34.

[6] Sachin Parmar, Amit Gangwal, Navin Sheth Issn 0975-5071usa Coden: Dpleb4.

[7] Ash L, Orihel Tc: Parasites: A Guide To Laboratory Procedures And Identification. American Society Of Clinical Pathologists, Chicago, 1987 .

[8] Bogitsh Bj And Cheng Tc: Human Parasitology. Wb Saunders, Philadelphia, 1990.

[9] Http://Www.Ncbi.Nlm.Nih.Gov/Books/Nbk8282/.Lustigman S, Prichard Rk, Gazzinelli A, Grant Wn, Boatin Ba, Mccarthy Js, Basáñez Mg (2012). "A Research Agenda For Helminth Diseases Of Humans: The Problem Of Helminthiases". Doi:10.1371/Journal.Pntd.0001582. Pmc 3335854. Pmid 22545164.

[10] Crompton Dwt, Savioli L (2007). Handbook Of Helminthiasis For Public Health. Crc Press, Boca Raton, Florida, Us. Pp. 1-362. Isbn 1420004946.

[11] Who (2012). "Research Priorities For Helminth Infections". World Health Organization Technical Report Series 972: 1-174. Pmid 23420950

[12] Van Riet E, Hartgers Fc, Yazdanbakhsh M (2007). "Chronic Helminth Infections Induce Immunomodulation: Consequences And Mechanisms". Immunobiology 212 (6): 475-9. Pmid 17544832

[13] Mkhize-Kwitshana Zl, Mabaso Mh (2012). "Status Of Medical Parasitology In South Africa: New Challenges And Missed Opportunities". Trends In Parasitology 28 (6): 217-219. Doi:10.1016/J.Pt.2012.03.005. Pmid 22525798 
[14] Prichard Rk, Basáñez Mg, Boatin Ba, Mccarthy Js, García Hh, Yang Gj, Sripa B, Lustigman S (2012). "A Research Agenda For Helminth Diseases Of Humans: Intervention For Control And Elimination". Plos Negl Trop Dis 6 (4): E1549. Doi:10.1371/Journal.Pntd.0001549. Pmc Pmc3335868

[15] Who (2006). Preventive Chemotherapy In Human Helminthiasis : Coordinated Use Of Anthelminthic Drugs In Control Interventions : A Manual For Health Professionals And Programme Managers. Who Press, World Health Organization, Geneva, Switzerland. Pp. 1-61. Isbn 9241547103

[16] Http://En.Wikipedia.Org/Wiki/Helminthiasis

[17] Perumal Samy R, Ignacimuthu S. (1998)J. Ethnopharmacol. 62: 173-182.

[18] Perumal Samy R, Ignacimuthu S. (2000) J. Ethnopharmacol. 69: 63-71.

[19] John D. (1984) Int. J. Crude Drug Res. 22: 17-39.

[20] Pushpangadan P, Atal Ck. (1984) J. Ethnopharmacol. 11: 59-77

[21] Ambasta, S. P., 1992. The Useful Plants Of India, Publication \& Information Directorate, Csir, New Delhi.

[22] Chopra, R. N., Nayar, S. L And I. C. Chopra., 1956. Glossary Of Indian Medicinal Plants, Council Of Scientific And Industrial Research, New Delhi.

[23] Abid, M., M. Ahmad, A. Jabeen, M. Zafar And S. Nadeem. 2005.Pharmacognostic Studies Of Some Indigenous Medicinal Plants Of Pakistan. J. Ethnobotanical Leaflets. Http://Www.Siu.Edu/ Ebl/Leaflets

[24] Abbasi And S.U. Din. 2010. Use Of Chemotaxonomic Markers For Misidentified Medicinal Plants Used In Traditional Medicines. J. Medicinal Plant Res., 4(13): 1244-1252.

[25] Davis Ph, Robson Mc (1999). Anti-Inflammatory And Wound Healing Of Growth Substances In Aloe Vera. J. Ame. Pediatric Med. Assoc. 84: 77-81.

[26] Esonu Bomn, Opara Ic, Okoli Ho, Obikaonu C, Udedibie, Iheshiulor Oom (2006). Physiological Responses Of Laying Birds To Neem (Azadirachta Indica) Leaf Meal Based Diets, Body Weight, Organ.

[27] Windholz M. Ed (1987) The Merck Index. 10th Edition. Rahway, Nj: Merck And Co.

[28] Grainage, M, Ahmed S.(1988) Handbook Of Plants With Pest-Control Properties. Wily-Interscience, New York

[29] Windholz M. Ed (1983) The Merck Index. 10th Edition. Rahway, Nj: Merck And Co.

[30] Dixit Vp, Et Al. (1986) J.Ethnopharmacol. 17:95-98 